\title{
Long-term effects of good handling practices during the pre-weaning period of crossbred dairy heifer calves
}

\author{
Luciana Pontes Silva $^{1,2}$ • Aline Cristina Sant'Anna ${ }^{2,3}$ - Lívia Carolina Magalhães Silva ${ }^{2}$. \\ Mateus José Rodrigues Paranhos da Costa ${ }^{2,4}$
}

Received: 29 September 2015 / Accepted: 12 October 2016/Published online: 26 October 2016

(C) Springer Science+Business Media Dordrecht 2016

\begin{abstract}
The aim of this study was to determine whether applying good practices of handling during the pre-weaning period have long-term effects on behavioral and physiological indicators, health status, and average daily gain (ADG) of crossbred Bos taurus $\times$ Bos indicus heifer calves. During the pre-weaning period, 98 crossbred of Holstein $\times$ Gir heifer calves were allotted into three treatments: (1) good practices of handling + brushing (GPB; $n=25)$, (2) good practices of handling (GP; $n=25)$, and (3) control $(n=48)$. Every 2 months, four evaluation periods $\left(\mathrm{EV}_{1}\right.$ to $\left.\mathrm{EV}_{4}\right)$ were conducted to record data. Behavioral indicators comprised time to drive (TD), flight speed (FS), flight distance (FD), and composite reactivity score (CRS). Physiological indicators of acute stress during handling comprised respiratory and heart rates. Health status comprised data regarding occurrence of most common diseases (i.e., pneumonia and anaplasmosis). Collected data were analyzed by using a linear mixed model for repeated measures, Tukey's test, and chi-squared procedures. Treatment influenced $(P<0.05)$ TD, FS, and FD but not CRS $(P=0.78)$. From $\mathrm{EV}_{1}$ to $\mathrm{EV}_{3}$, the control calves had the lowest TD. The GPB group had lower FS than the control but did not differ from GP. The GPB group had lower FD
\end{abstract}

Mateus José Rodrigues Paranhos da Costa mpcosta@fcav.unesp.br

1 Programa de Pós-Graduação em Zootecnia, FCAV-UNESP, 14884-900 Jaboticabal, SP, Brazil

2 Grupo de Estudos e Pesquisas em Etologia e Ecologia Animal (Grupo ETCO), Departamento de Zootecnia, FCAV-UNESP, 14884-900 Jaboticabal, SP, Brazil

3 Departamento de Zoologia, ICB-UFJF, 36036-900 Juiz de Fora, MG, Brazil

4 Pesquisador CNPq, Brasília, DF, Brazil means than the other two groups in $\mathrm{EV}_{2}, \mathrm{EV}_{3}$, and $\mathrm{EV}_{4}$. No differences $(P>0.05)$ due to treatment were observed on heart and respiratory rates, $\mathrm{ADG}$, or occurrence of pneumonia and anaplasmosis. It was concluded that adoption of good practices of handling during pre-weaning period may lead to longterm positive effects.

Keywords Animal welfare $\cdot$ Calves $\cdot$ Calf handling . Temperament

\section{Introduction}

The welfare of dairy calves is often compromised due to farmers' effort to decrease the cost-benefit ratio of calf rearing (Vasseur et al. 2010). However, the success of the rearing period significantly affects the entire production system due to its close relationship with reproduction, milk production, and health (Svensson and Hultgren 2008; Hultgren and Svensson 2009a, b). During the rearing period, the adoption of positive handling practices (e.g., gentle contact, brushing and stroking, human presence during feeding, and soft talking) contribute to reduce animals' fear to humans and reactivity to handling, which in turn results in improved welfare and productivity (Breuer et al. 2000; Hemsworth et al. 2000; Lensink et al. 2000a).

Gentle and pleasant tactile contact has beneficial effects on human-animal interactions (Schuelze-Westerath et al. 2014). Several studies have also addressed the beneficial effects of contact on the behavior and productivity of dairy cattle at different stages, such as pre-weaning (Boissy and Bouissou 1988; Boivin et al. 1992; Jago et al. 1999; Lensink et al. 2000a, b; Krohn et al. 2001), pre-calving (Kerr and WoodGush 1987; Breuer et al. 2003; Bertenshaw et al. 2008), milking (Pajor et al. 2000; Rushen et al. 2001; Schmied 
et al. 2008a, b), and reproductive handling procedures (Waiblinger et al. 2004).

Although several studies have reported on the beneficial effects of gentle tactile contact during the pre-weaning and post-weaning periods (Boivin et al. 1992; Jago et al. 1999; Lensink et al. 2000a, b; Krohn et al. 2001), most of these focused on the immediate or early impact of positive handling (Boivin et al. 1992; Jago et al. 1999; Lensink et al. 2000a, b; Krohn et al. 2001). Therefore, whether positive handling practices have long-term effects on cattle behavior and welfare remains unknown. Furthermore, previous studies have mostly focused on Bos taurus dairy breeds such as Holstein-Friesian (Boissy and Bouissou 1988; Boivin et al. 1992; Jago et al. 1999; Lensink et al. 2000a, b; Krohn et al. 2001), which are largely selected for their low reactivity to human handling (Jago et al. 1999). Less attention has been given to other more excitable and temperamental cattle such as the zebu (Bos indicus) and zebu-derived breeds (e.g., Gyr and Girolando), which are particularly important for tropical climate farming. Therefore, this study aimed to investigate whether positive handling practices during the pre-weaning period have longterm effects on crossbred taurus-indicus female heifer calves.

\section{Materials and methods}

\section{Location}

This study was conducted on a private dairy farm (Fazenda Santa Luzia, Southern Minas Gerais, Brazil; latitude $20^{\circ} 43^{\prime} \mathrm{S}$, longitude $46^{\circ} 36^{\prime} \mathrm{W}$ ) with a mean altitude of $745 \mathrm{~m}$ above sea level, warm temperate climate with dry winters and hot summers (type Cwa, according to the Köppen classification), average temperature above $18{ }^{\circ} \mathrm{C}$, and annual precipitation of 1.709.4 mm. On this farm, milk is produced using a herd of crossbred B. taurus $\times B$. indicus cows composed of different admixture of Holstein $(\mathrm{H}) \times$ Gir $(\mathrm{G})$ females (Brazilian Girolando), which were handled on fertilized pastures and access to supplemental feeding.

Girolando is a composite breed in which an open record is handled. Although the final objective is to consolidate the breed as (5/8 Holstein $+3 / 8$ Gir), up-to-date, animals in between $(3 / 4$ Gir $+1 / 4$ Holstein) to $(7 / 8$ Holstein $+1 / 8$ Gir $)$ are registered by the breed association.

\section{Animals}

A group of 98 crossbred heifer calves was used in this study. All calves were contemporaneous in age and included in the study according the following inclusion-exclusion criteria: healthy, born from multiparous cows, eutocic delivery, and appropriate birth weight for their breed type $(33.5 \pm 4.7 \mathrm{~kg})$. The calves were assigned into three genetic groups as to avoid differences according breed admixture $(1 / 2 \mathrm{H}+1 / 2 \mathrm{G} ; 3 / 4 \mathrm{H}+$ $1 / 4 \mathrm{G}, 5 / 8 \mathrm{H}+3 / 8 \mathrm{G}$ (named here as Girolando); and 7/8 H + $1 / 8 \mathrm{G})$ among experimental groups $\left(\chi^{2}=8.71 ; P=0.07\right.$; Table 1).

\section{Housing, handling, and feeding}

Pre-weaning period From the second day of life to weaning, the calves were housed in an outdoor system known as "tropical housing." The calves were neck-tied to a 2-m chain that was fixed to a 10-m wire stretched on the ground (which was in turn tied to $10-\mathrm{cm}$-tall wood posts). Thus, the calves had access to an area of about $40 \mathrm{~m}^{2}$ that was mostly covered by Tifton 85 Bermuda grass (Cynodon spp.). The calves were able to have physical contact with as many as two other calves and visual contact with several. Also, each calf had access to $8 \mathrm{~m}^{2}$ of shade provided by a shading screen. Water and concentrate (18\% crude protein) were offered ad libitum. The calves were milk-fed until weaning according to their assigned experimental treatment. During the 7 days prior to weaning, the calves received water and a solid diet only. Weaning occurred when the calves were about 70 days old, above $70 \mathrm{~kg}$, and consumed at least $700 \mathrm{~g} /$ day of concentrate.

After weaning, the calves underwent 10 days of transitional handling in order to adapt to the nutritional and environmental conditions of the post-weaning phase. They were kept in paddocks in groups of around 20 calves of similar body weight from all 3 treatment groups and even calves that were not part of the study. They were initially fed with the pre-weaning concentrate, and a total mixed ration (17\% crude protein) was gradually added to their diet, consisting of $50 \%$ concentrate and $50 \%$ Napier grass (Pennisetum purpureum) silage plus mineral mixture.

Post-weaning period Following the transition period ( $\sim 10$ days), the calves were moved to different paddocks, where they were also grouped with animals from all three treatments as well as calves that were not part of the study. During the post-weaning phase, the calves were divided in groups by the farm team (following managerial decisions)

Table 1 Number of calves from each genetic group per treatment

\begin{tabular}{lllll}
\hline Genetic groups & GPB & GP & Control & Total \\
\hline 1/2 HG & 6 & 3 & 3 & 12 \\
Girolando (3/4 and 5/8 HG) & 10 & 10 & 31 & 51 \\
7/8 HG & 9 & 12 & 14 & 35 \\
Total & 25 & 25 & 48 & 98 \\
\hline
\end{tabular}

$G P B$ good practices of handling plus brushing, $G P$ good practices of handling, control control group, $1 / 2 H G 1 / 2$ Holstein $(\mathrm{H})+1 / 2$ Gyr $(\mathrm{G})$ racial composition, Girolando $3 / 4 \mathrm{H}+1 / 4 \mathrm{G}$ and $5 / 8 \mathrm{H}+3 / 8 \mathrm{G}$ racial compositions, 7/8 HG 7/8 $\mathrm{H}+1 / 8 \mathrm{G}$ racial composition 
based on age and paddock characteristics (from 81 to 200 days of life, groups had 35 heifer calves; from 201 to 300 days of age, groups had 120 heifer calves; and above 300 days, groups had 150 heifers). The calves were fed the total mixed ration and had the opportunity to graze Tifton 85 Bermuda grass (Cynodon spp.).

All animals were submitted to the following vaccination and deworming schedules: vaccines against clostridiosis, rabies, and leptospirosis around 90 days of life (with a booster dose after 30 days); against brucellosis at around 6 months of life; and against foot and mouth disease twice a year (in May and November) for animals up to 24 months of age. All calves were dewormed using albendazole (an oral broad-spectrum anthelmintic agent) at weaning and at 4, 5, and 6 months of age.

The handling procedures and the behavioral tests were carried out in a conventional Brazilian corral, with a straight open side chute. All handlers were previously trained in good practices of cattle handling, and the use of flags was part of their daily routine.

\section{Experimental procedures}

This field study was conducted using a factorial design, considering three treatments and three genetic groups, with repeated measurements over time. The calves were randomly assigned into one of three treatments $(\mathrm{GPB}=$ good practices of handling plus brushing, $n=25$; GP $=$ good practices of handling, $n=25$; and control, $n=48$ ), according to birth sequence.

The good practices of handling (applied to GPB and GP treatments) consisted of navel disinfection within $3 \mathrm{~h}$ of birth (10\% iodine solution) and colostrum feeding $(6 \mathrm{~L}$ within $12 \mathrm{~h}$ of birth, including $2 \mathrm{~L}$ within the first $3 \mathrm{~h}$ ). Colostrum quality was assured (temperature between 35 and $37^{\circ} \mathrm{C}$, immunoglobulin at least $51 \mathrm{mg} / \mathrm{mL}$ of IgG, measured using a Nasco Farm \& Ranch ${ }^{\circledR}$ colostrometer). From the 2 nd to the 35 th day of life, the calves were milk-fed using teat buckets $(6 \mathrm{~L} /$ day divided into two meals). Then, from the 36th day to weaning, the calves were fed $3 \mathrm{~L}$ once a day. During the morning milk feeding, the GPB calves were brushed for $5 \mathrm{~min}$ (using a soft brush on the back, base of the tail, groin, and head) to simulate licking by a cow. The calves in the control group remained with the dams during the first $24 \mathrm{~h}$ of life, which is the standard handling procedure used on the farm. Thus, the control calves suckled colostrum directly from their dams, which precludes the assessment of quality or the time elapsed since birth. Navel disinfection was performed during the first $24 \mathrm{~h}$ of life without controlling the time between calving and disinfection. Following colostrum feeding, the calves in the control group received the same liquid feeding program as GPB and GP calves (i.e., $6 \mathrm{~L}$ of milk/day divided in two meals from the 2 nd to the 35 th day of life and $3 \mathrm{~L}$ once a day from the 36th to weaning) but using buckets with no teats and receiving no human contact other than involved in feeding and veterinary procedures (vaccination, deworming, or treatments against diseases). The control group underwent the usual management practices applied in most Brazilian dairy farms, which involve providing controlled amounts of milk (usually $4 \mathrm{~L}$ per day) in buckets without teats, little human contact, and individual housing, while maintaining the calves tied by the neck with 1.5-m chains (Miranda et al. 2003; Campos and Campos 2004).

Temperament traits Across the study, heifer calf temperament was evaluated in a handling corral every 2 months. Four evaluations (EVs) were performed when animals had $170 \pm 30\left(\mathrm{EV}_{1}\right), 248 \pm 30\left(\mathrm{EV}_{2}\right), 318 \pm 29\left(\mathrm{EV}_{3}\right)$, and $376 \pm$ $29\left(\mathrm{EV}_{4}\right)$ days of age. Here, a handler familiar to the animals drove them into the corral while three observers unfamiliar to animals and blind to the treatments recorded data to assess temperament to calve heifers from each group in a random sequence. In order to assess temperament, the following four behavioral indicators of reaction to handling were used: time to drive (TD; adapted from Pajor et al. 2000), composite reactivity score (CRS; adapted from Fordyce et al. 1985), flight speed (FS; Burrow and Corbet 2000), and flight distance (FD). Full description of the methods is offered in Table 2.

Physiological indicators The following two physiological indicators of acute stress were used to measure heifer calves' response to handling: heart rate (in beats/min; measured by cardiac auscultation) and respiratory rate (in movements/min; recorded by counting thoracic breathing movements). Both measurements were performed at $\mathrm{EV}_{2}, \mathrm{EV}_{3}$, and $\mathrm{EV}_{4}$ with animals in the squeeze chute without the head bail restraint, immediately after the observer recorded the CRS and before applying the FS and FD tests.

Health indicators Pneumonia and bovine anaplasmosis were the most common diseases affecting calves during the postweaning period. The number of episodes per calf of these diseases between October 2013 and May 2014 was obtained from farm records. At the farm, herd health was daily monitored by a trained stockperson who recorded clinical signs and symptoms of diseases.

Average daily gain The average daily gain (ADG) was calculated by comparing weight at weaning to that measured during the temperament assessments at $170 \pm 30,248 \pm 30$, $318 \pm 29$, and $376 \pm 29$ days of age $\left(\mathrm{EV}_{1}\right.$ to $\mathrm{EV}_{4}$, respectively).

\section{Statistical analysis}

The effect of treatment on temperament traits (TD, CRS, FS, and FD), physiological indicators (heart and respiratory rates), and ADG was assessed by fitting a linear mixed-effect model 
Table 2 Description of the methods used to assess heifer calf temperament

Trait Description and procedures

Time to drive(TD)

Composite reactivity score (CRS)

Movement score

Tension score

Breathing score

Vocalization

Kicking

Flight speed (FS)

Flight distance (FD)
Description: time (in s) taken to drive each calf along an aisle $8 \mathrm{~m}$ long and $0.7 \mathrm{~m}$ wide until entering the squeeze chute. The handler follows a standardized sequence of actions with increasing stimulus intensity, changing every $10 \mathrm{~s}$ if the previous action did not drive the heifer into the squeeze chute.

Procedure: heifers are placed individually at the beginning of the race and then first — each heifer is allowed to move through the race into the squeeze chute without any human interference for $10 \mathrm{~s}$; second - the handler walks along the aisle, crossing the heifer's balance point, holding a flag to stimulate the heifer to move for $10 \mathrm{~s}$; third — voice commands are added to the previous action for $10 \mathrm{~s}$; fourth — physical stimulation, the heifer's back is touched with the hands, and voice commands are given for $10 \mathrm{~s}$; fifth - the base of the heifer's tail is held, lifting and pushing it forward (without twisting the tail), forcing the heifer to move forward.

Description: assesses heifers' overall reactivity inside the squeeze chute for $4 \mathrm{~s}$, just after their entrance, without physical restraint on a head bail.

Procedure: five visual scores are summed to obtain a single measure of reactivity $=$ movement score + tension score + breathing score + vocalization + kicking.

$1=$ no movement; $2=$ little movement, during less than half of the observation time; $3=$ frequent movements (half of the observation time or more), but not vigorous; $4=$ constant and vigorous movements; $5=$ vigorous movements, jumps and raises the forelimbs off the ground.

$1=$ animal did not exhibit sudden movements of the tail, head, and neck, no muscle tremors, and white of eye was not visible; 2 = animal exhibited few sudden movements of the tail, head, and neck, no muscle tremors, and white of eye was visible or not; 3 = animal exhibited continuous and vigorous movements of the tail, head, and neck, white of eye was visible, no visible muscle tremors; 4 = animal appeared paralyzed,

"freezing" reaction, visible muscle tremors.

$1=$ normal and rhythmic breathing; $2=$ audible and not rhythmic breathing, blowing

$1=$ no vocalization; $2=$ vocalization

$1=$ no kicks; 2 = kicks

Description: speed at which the heifers exit the squeeze chute. Faster animals are deemed more excitable.

Procedure: an electronic device is used to record the time (s) taken by each animal to cover a known distance $(1.53$ and $2.0 \mathrm{~m})$, later converted to speed $(\mathrm{m} / \mathrm{s})$.

Description: distance at which calves allowed a non-familiar human to approach them before first showing withdrawal.

Procedure: applied with calves kept individually in a pen of the corral, immediately after the other temperament tests. We conducted two FD trials and averaged them together. for repeated measures, using PROC MIXED (SAS 2011). Statistical models included the fixed effects of evaluation $\left(\mathrm{EV}_{1,2,3,4}\right)$, treatment nested within evaluation, genetic group, animal age at the time of evaluation, and the interaction of treatment $\times$ evaluation $\times$ genetic group. Animal (subject) was included as a random effect repeated within each evaluation. The interaction of treatment $\times$ evaluation $\times$ genetic group was excluded from all final models due to lack of significance $(P>0.05$, for heart rate, respiratory rate, TD, FS, and FD), although for CRS, it was significant $(P=0.03)$ and the same final model was used. Normal distribution of all variables was visually tested by plotting raw and studentized residuals. Data for TD was not normally distributed, and hence, log-transformation was applied. The Bayesian information criterion was used to select covariance structure of residuals. For mean comparison, the post hoc Tukey test was applied. Significance of $P$ values was pre-established at $P<0.05$. In order to test whether the incidence of anaplasmosis and pneumonia differed among treatments, chi-squared procedure was applied.

\section{Results}

\section{Temperament traits}

As shown in Table 3, treatment influenced TD $(F=2.67, P=$ 0.008). In the first three assessments $\left(\mathrm{EV}_{1}\right.$ to $\left.\mathrm{EV}_{3}\right)$, the control group had the lowest TD when compared to GP $\left(\mathrm{EV}_{1}\right.$ to $\left.\mathrm{EV}_{2}\right)$ and $\mathrm{GBP}\left(\mathrm{EV}_{3}\right)$. However, no differences $(P>0.05)$ among treatments were observed in $\mathrm{EV}_{4}$ (Table 4). Treatment also influenced FS $(F=2.13$, $P=0.033)$. In the first three assessments $\left(\mathrm{EV}_{1}\right.$ to $\left.\mathrm{EV}_{3}\right)$, the GBP group had lower FS compared to the control group but did not differ from the GP group. In addition, treatment also influenced FD $(F=3.81, P<0.001)$. From $\mathrm{EV}_{2}$ to $\mathrm{EV}_{4}$, the GBP group had lower FD than the GP and control groups (Table 4). Finally, treatment did not influenced CRS $(F=0.59, P=0.785)$.

Genetic group affected all temperament traits, TD $(F=4.83, P=0.009)$, CRS $(F=3.82, P=0.023)$, FS $(F=12.18, P<0.001)$, and FD $(F=4.94, P=0.008)$. The $1 / 2$ 
Table 3 Summary of fixed effects, including all the dependent variables

\begin{tabular}{|c|c|c|c|c|}
\hline Dependent variables & Source of variation & $d f$ & $F$ & $P$ values \\
\hline \multirow[t]{4}{*}{ Time to drive (TD) } & Evaluation & 3 & 9.90 & $<0.001$ \\
\hline & Treatment within EV & 8 & 2.67 & 0.008 \\
\hline & Age & 10 & 1.72 & 0.076 \\
\hline & Genetic group & 2 & 4.83 & 0.009 \\
\hline \multirow[t]{4}{*}{ Composite reactivity score (CRS) } & Evaluation & 3 & 1.09 & 0.354 \\
\hline & Treatment within EV & 8 & 0.59 & 0.785 \\
\hline & Age & 10 & 1.94 & 0.039 \\
\hline & Genetic group & 2 & 3.82 & 0.023 \\
\hline \multirow[t]{4}{*}{ Flight speed (FS) } & Evaluation & 3 & 0.84 & 0.472 \\
\hline & Treatment within EV & 8 & 2.13 & 0.033 \\
\hline & Age & 10 & 2.65 & 0.004 \\
\hline & Genetic group & 2 & 12.18 & $<0.001$ \\
\hline \multirow[t]{4}{*}{ Flight distance (FD) } & Evaluation & 3 & 30.86 & $<0.001$ \\
\hline & Treatment within EV & 8 & 3.81 & $<0.001$ \\
\hline & Age & 2 & 1.95 & 0.039 \\
\hline & Genetic group & 10 & 4.94 & 0.008 \\
\hline \multirow[t]{4}{*}{ Respiratory rate } & Evaluation & 2 & 5.55 & 0.005 \\
\hline & Treatment within EV & 6 & 1.21 & 0.304 \\
\hline & Age & 8 & 1.96 & 0.053 \\
\hline & Genetic group & 2 & 1.28 & 0.279 \\
\hline \multirow[t]{4}{*}{ Heart rate } & Evaluation & 2 & 20.28 & $<0.001$ \\
\hline & Treatment within EV & 6 & 0.80 & 0.572 \\
\hline & Age & 8 & 0.38 & 0.932 \\
\hline & Genetic group & 2 & 1.37 & 0.256 \\
\hline \multirow[t]{4}{*}{ Average daily gain (ADG) } & Evaluation & 3 & 91.90 & $<0.001$ \\
\hline & Treatment within EV & 8 & 0.64 & 0.742 \\
\hline & Age & 10 & 4.23 & $<0.001$ \\
\hline & Genetic group & 2 & 2.18 & 0.115 \\
\hline
\end{tabular}

$E V$ evaluation, $d f$ degrees of freedom
HG heifer calves had lower TD and higher CRS, FS, and FD when compared to the $7 / 8 \mathrm{HG}$ calves (Table 5). Girolando (3/4 HG and 5/8 HG) calves were similar to $1 / 2 \mathrm{HG}$ heifers for TD, CRS, and FS but were similar to $7 / 8 \mathrm{HG}$ calves in terms of FD (Table 5).

\section{Physiological indicators, health indicators, and average daily gain}

Treatment had no effect on either respiratory $(F=1.21$, $P=0.304)$ or heart rate $(F=0.80, P=0.572)$. However, a Tukey's mean comparison test showed that the GPB group had lower heart and respiratory rates at $\mathrm{EV}_{2}$ and $\mathrm{EV}_{4}$, respectively (Table 6). No effect of the genetic group was found on respiratory $(F=1.28, P=0.279)$ or heart rate $(F=1.37, P=$ $0.256)$.

Treatment also did not affect the incidence of bovine anaplasmosis $\left(\chi^{2}=9.365, d f=6, P=0.154\right)$ or pneumonia $\left(\chi^{2}=10.363, d f=6, P=0.110\right.$ ) (Fig. 1), and the same was true for the genetic group (pneumonia, $\chi^{2}=4.123, d f=6, P=0.660$ and bovine anaplasmosis, $\chi^{2}=5.814, d f=6, P=0.444$ ) (Fig. 2). Finally, neither treatment nor genetic group had a significant effect on ADG ( $F=0.64, P=0.742$ and $F=2.18$, $P=0.115$, respectively).

\section{Discussion}

Our results show that good practices of handling improve heifer calves' temperament and indicate that brushing might have a positive long-term effect, especially on FD. However, no significant long-term effects of these practices were found for heifer growth or health. Regarding the genetic group, our results confirmed the expectation (da Costa et al. 2015) that increasing the proportion of zebu breed may worsen temperament. 
Table 4 Means $( \pm$ SE) of time to drive (TD) the calves into the squeeze chute, composite reactivity score (CRS), flight speed (FS), and flight distance (FD) for the three treatments (GPB, GP, and control) for all four evaluation times $\left(\mathrm{EV}_{1}-\mathrm{EV}_{4}\right)$

\begin{tabular}{lllll}
\hline Dependent variables & $\mathrm{EV}_{1}$ & $\mathrm{EV}_{2}$ & $\mathrm{EV}_{3}$ & $\mathrm{EV}_{4}$ \\
\hline $\mathrm{TD}(\mathrm{s})$ & & & & \\
GPB & $38.63 \mathrm{a} \pm 7.20$ & $13.66 \mathrm{~b} \pm 3.93$ & $35.45 \mathrm{a} \pm 4.66$ & $26.68 \mathrm{a} \pm 5.90$ \\
GP & $41.53 \mathrm{a} \pm 7.60$ & $24.55 \mathrm{a} \pm 4.41$ & $28.34 \mathrm{ab} \pm 4.83$ & $29.75 \mathrm{a} \pm 5.84$ \\
Control & $25.40 \mathrm{~b} \pm 6.21$ & $9.52 \mathrm{~b} \pm 3.69$ & $23.90 \mathrm{~b} \pm 3.99$ & $21.25 \mathrm{a} \pm 5.18$ \\
CRS & & & & \\
GPB & $3.88 \mathrm{a} \pm 0.45$ & $3.20 \mathrm{a} \pm 0.37$ & $2.68 \mathrm{a} \pm 0.36$ & $2.80 \mathrm{a} \pm 0.42$ \\
GP & $3.60 \mathrm{a} \pm 0.47$ & $3.63 \mathrm{a} \pm 0.42$ & $2.78 \mathrm{a} \pm 0.38$ & $3.07 \mathrm{a} \pm 0.42$ \\
Control & $3.44 \mathrm{a} \pm 0.42$ & $3.55 \mathrm{a} \pm 0.32$ & $3.02 \mathrm{a} \pm 0.32$ & $3.27 \mathrm{a} \pm 0.38$ \\
FS (m/s) & & & & \\
GPB & $1.19 \mathrm{~b} \pm 0.16$ & $0.97 \mathrm{~b} \pm 0.13$ & $0.82 \mathrm{~b} \pm 0.13$ & $0.92 \mathrm{a} \pm 0.15$ \\
GP & $1.32 \mathrm{ab} \pm 0.17$ & $1.16 \mathrm{ab} \pm 0.15$ & $1.05 \mathrm{ab} \pm 0.14$ & $1.03 \mathrm{a} \pm 0.15$ \\
Control & $1.47 \mathrm{a} \pm 0.15$ & $1.31 \mathrm{a} \pm 0.12$ & $1.17 \mathrm{a} \pm 0.12$ & $1.12 \mathrm{a} \pm 0.14$ \\
FD (m) & & & & \\
GPB & $5.65 \mathrm{a} \pm 0.57$ & $6.04 \mathrm{~b} \pm 0.51$ & $2.53 \mathrm{~b} \pm 0.31$ & $3.74 \mathrm{~b} \pm 0.50$ \\
GP & $5.73 \mathrm{a} \pm 0.59$ & $6.30 \mathrm{ab} \pm 0.55$ & $3.30 \mathrm{a} \pm 0.32$ & $5.03 \mathrm{a} \pm 0.49$ \\
Control & $6.00 \mathrm{a} \pm 0.52$ & $7.08 \mathrm{a} \pm 0.41$ & $3.53 \mathrm{a} \pm 0.30$ & $5.40 \mathrm{a} \pm 0.43$ \\
\hline
\end{tabular}

Means within a column with the same lowercase letter do not differ from each other; Tukey's test $(P>0.10)$ $G P B$ good practices of handling plus brushing, $G P$ good practices of handling, control control group
In a study by Pajor et al. (2000), fearful animals that received an aversive treatment took a longer time to move through an alley leading to a treatment area (the cattle crush). By contrast, in the present study, more agitated and fearful animals took a faster time to reach the squeeze chute. This apparent discrepancy may be explained by the different study designs. In Pajor et al. (2000), adult cows underwent a learning period immediately before the test, in which they entered the treatment area (crush) and received positive or aversive treatments, which affected their entrance time. In the present study, heifer calves did not undergo a learning period nor treatments inside the squeeze chute; they were not driven to the corral in the pre-weaning period, and after being weaned, they were infrequently handled in the corral (about every 60 days). The faster time (lower TD) exhibited by the control calves entering the squeeze chute may be interpreted as an attempt to avoid close contact with the person who performed the driving and to quickly exit such a handling situation. A similar behavior was reported by Boivin et al. (1992) for dairy calves with little previous contact with humans. In that study, the calves were probably able to recognize the door as an exit and thus fled more easily from the experimenter.

FS is an indicator of general fear and agitation that is traditionally used in the evaluation of beef cattle temperament. It is influenced by genetic factors (Burrow and Corbet 2000; Sant'Anna et al. 2013) and previous experiences, such as positive or negative handling (Petherick et al. 2009). Although it is not as commonly used with dairy cattle, this test proved to be a useful indicator of "responsiveness" to handling in HolsteinFriesians dairy heifers (Gibbons et al. 2011). Similarly, in the current study, we observed that the control group had a higher FS than the GP and GPB groups. Moreover, the GP and GPB groups did not differ from each other, showing that brushing during the preweaning period did not have long-term effects on FS.

On the other hand, the FD test revealed significant differences between calves in the GPB and GP groups, with lower
Table 5 Means $( \pm$ SE) of time to drive (TD in $\mathrm{s}$ ) the calves into the squeeze chute, composite reactivity score (CRS), flight speed (FS in $\mathrm{m} / \mathrm{s}$ ), and flight distance (FD in $\mathrm{m}$ ), according to genetic group

\begin{tabular}{llllll}
\hline Genetic groups & Number & TD & CRS & FS & FD \\
\hline $1 / 2 \mathrm{HG}$ & 12 & $23.51 \mathrm{~b} \pm 3.14$ & $3.60 \mathrm{a} \pm 0.23$ & $1.32 \mathrm{a} \pm 0.08$ & $5.53 \mathrm{a} \pm 0.24$ \\
Girolando & 51 & $24.08 \mathrm{~b} \pm 1.91$ & $3.27 \mathrm{a} \pm 0.13$ & $1.18 \mathrm{a} \pm 0.05$ & $4.89 \mathrm{~b} \pm 0.15$ \\
$7 / 8 \mathrm{HG}$ & 35 & $32.08 \mathrm{a} \pm 2.12$ & $2.87 \mathrm{~b} \pm 0.15$ & $0.89 \mathrm{~b} \pm 0.06$ & $4.65 \mathrm{~b} \pm 0.17$ \\
\hline
\end{tabular}

Means within a column with the same lowercase letter do not differ from each other; Tukey's test $(P>0.10)$ $1 / 2 H G 1 / 2$ Holstein $(\mathrm{H})+1 / 2 \mathrm{Gyr}(\mathrm{G})$ racial composition, Girolando $3 / 4 \mathrm{H}+1 / 4 \mathrm{G}$ and $5 / 8 \mathrm{H}+3 / 8 \mathrm{G}$ racial compositions, $7 / 8 H G 7 / 8 \mathrm{H}+1 / 8 \mathrm{G}$ racial composition 
Table 6 Means $( \pm \mathrm{SE})$ of respiratory and heart rates for the three treatments (GPB, GP, and control) and evaluation times $\mathrm{EV}_{2}-\mathrm{EV}_{4}$

\begin{tabular}{|c|c|c|c|}
\hline Dependent variable & $\mathrm{EV}_{2}$ & $\mathrm{EV}_{3}$ & $\mathrm{EV}_{4}$ \\
\hline \multicolumn{4}{|c|}{ Respiratory rate (movement/min) } \\
\hline GPB & $61.45 \mathrm{a} \pm 2.87$ & $53.45 \mathrm{a} \pm 2.22$ & $48.64 b \pm 2.51$ \\
\hline GP & $59.94 \mathrm{a} \pm 3.26$ & $56.88 \mathrm{a} \pm 2.35$ & $49.13 \mathrm{ab} \pm 2.49$ \\
\hline Control & $64.19 \mathrm{a} \pm 2.55$ & $56.42 \mathrm{a} \pm 1.95$ & $53.04 \mathrm{a} \pm 2.24$ \\
\hline \multicolumn{4}{|l|}{ Heart rate (beats/min) } \\
\hline GPB & $105.94 b \pm 4.66$ & $83.29 \mathrm{a} \pm 2.80$ & $88.14 \mathrm{a} \pm 2.95$ \\
\hline GP & $116.75 \mathrm{a} \pm 5.26$ & $83.37^{\mathrm{a}} \pm 2.98$ & $87.42 \mathrm{a} \pm 2.93$ \\
\hline Control & $108.00 \mathrm{ab} \pm 4.00$ & $86.01 \mathrm{a} \pm 2.54$ & $86.66 \mathrm{a} \pm 2.71$ \\
\hline
\end{tabular}

Means within a column with the same lowercase letter do not differ from each other; Tukey's test $(P>0.10)$

$G P B$ good practices of handling plus brushing, $G P$ good practices of handling, control control group

flight responses for the GPB calves. Although FS and FD responses have been shown to be correlated (Gibbons et al. 2011), FS is a more general indicator of fear (MacKay et al. 2013), while FD is specifically associated with fearfulness of humans (Waiblinger et al. 2006). Thus, while brushing during the pre-weaning period produced a long-term reduction in animals' fear of humans that was still observable months later, it had no effect on the general fear response. A similar result was reported by Lensink et al. (2000a) for veal calves, with no effect of gentle contact (stroking) on behavioral responses of calves to situations which did not involve human presence (novelty and surprise tests).

It is noteworthy that at $\mathrm{EV}_{1}$, FD did not differ significantly among the three groups. This may be explained by the fact that tests were conducted in the corral, a site unfamiliar to the heifers. Indeed, previous studies have shown that calves respond differently to human contact in unknown compared with familiar sites (Rushen et al. 1998; Jago et al. 1999). The decrease in FS and FD means over the four assessments suggests that the calves became habituated to handling in the corral and responded increasingly more naturally to human contact, as reflected by differences in FD among the three groups starting at $\mathrm{EV}_{2}$.

The reactivity test inside the squeeze chute (yielding a "crush" or a "movement" score on a 5-point scale) is typically used to assess beef cattle temperament (Fordyce et al. 1985; Burrow and Corbet 2000; Sant'Anna et al. 2013). In the present study, there were no differences in CRS among the three treatments, which may reflect lower reactivity by dairy calves relative to beef calves inside the crush. Gibbons et al. (2011) also observed low CRS variability in Holstein-Friesian dairy heifers on a test that uses a scale from 0 ("standing stationary, calm, no movement, no resistance") to 4 points ("active escape behavior, animal may kneel/fall"). According to these authors, only a more detailed and sensitive scoring system might detect differences among animals of dairy origin. Although we used zebu-crossed cattle and a more detailed composite score with a greater range (0 to 9 points), we consider TD, FS, and FD as being more sensitive measures of heifer temperament.

Because both physiological indicators are associated with the activity of the sympathetic nervous system, we expected that they would reflect activation of the sympathetic-adrenomedullary response to acute stress. However, our results should be interpreted with caution, because no significant effects of treatment were observed, and differences among groups were not consistent across assessments (the GPB heifers had a lower respiratory rate than the control group only at $\mathrm{EV}_{4}$, and at $\mathrm{EV}_{2}$, they had a lower heart rate than both the GP and control groups). In order to confirm that stimulated heifers are less susceptible to stress during handling, future studies should test other physiological measurements, such as plasma cortisol and glucose concentrations, and should measure the time needed to recover to basal levels.

In the current study, the adoption of good practices of handling during the early life of heifer calves did not show long-
Fig. 1 Percentage of animals with clinical signs of bovine anaplasmosis (a) and pneumonia (b) in each treatment group: $1=$ one occurrence of the disease; $2=$ two occurrences of the disease; and $3=$ recurrent cases, three or more occurrences of the disease. $G P B$ good practices of handling plus brushing, $G P$ good practices of handling

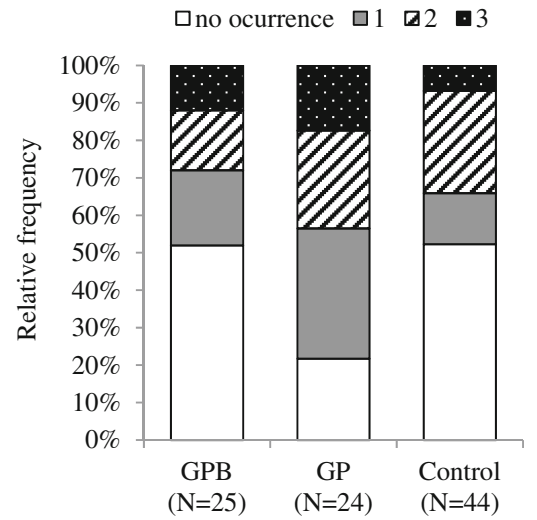

(A) Bovine anasplamosis

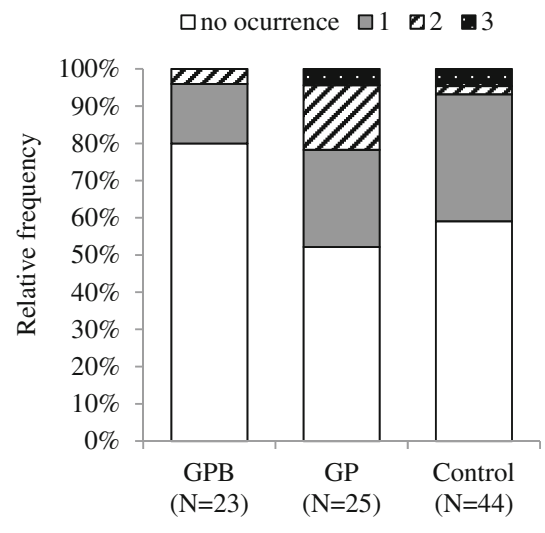

(B) Pneumonia 
Fig. 2 Percentage of occurrences of bovine anaplasmosis (a) and pneumonia (b) for each genetic group: $1=$ one occurrence of the disease; 2 = two occurrences of the disease; and $3=$ recurrent cases, three or more occurrences of the disease. $1 / 2 H G, 1 / 2$ Holstein $(\mathrm{H})+1 / 2$ Gyr $(\mathrm{G})$ racial composition, Girolando, 3/4 H + $1 / 4 \mathrm{G}$ and $5 / 8 \mathrm{H}+3 / 8 \mathrm{G}$ racial compositions, $7 / 8 H G, 7 / 8 \mathrm{H}+1 /$ $8 \mathrm{G}$ racial composition

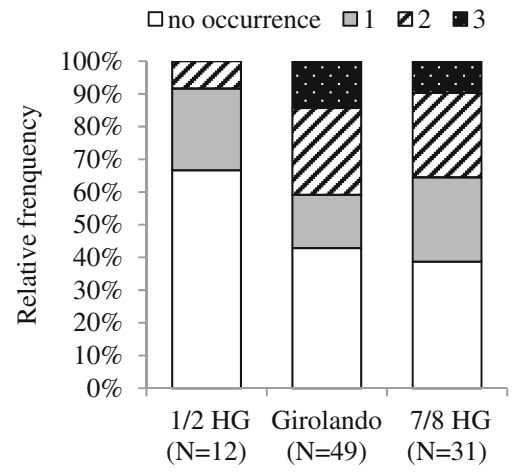

(A) Bovine anaplasmosis

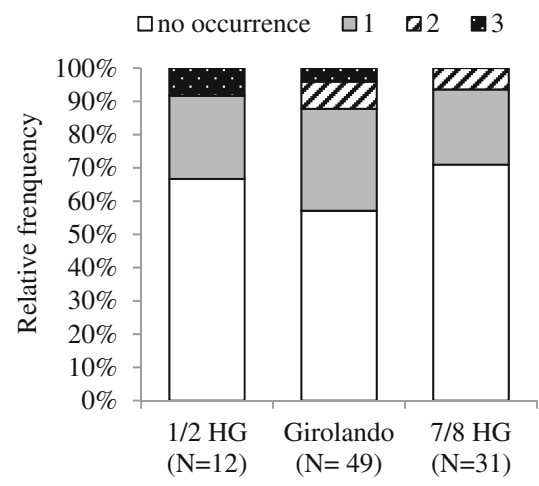

(B) Pneumonia term effects on calf growth. This result corroborates the findings of other authors who did not find any significant effect of brushing or stroking on the average daily gain of dairy calves (Jago et al. 1999; Lensink et al. 2000a).

Access to high-quality colostrum soon after birth grants calves passive immunity, assuring early life health, as well as long-term health and productivity (WaltnerToews et al. 1986). Since studies with other mammal species such as rats (Solomon et al. 1968), rhesus monkeys (Suomi 1995), humans (Field 1995), and dogs (Charnetski et al. 2004) suggest that tactile stimulation during infancy can positively affect immunity, we expected that adopting good practices of handling would lead to a lower incidence of diseases during the postweaning period in calves. However, our results did not confirm this expectation, with the chi-squared test revealing no association between treatments and the occurrence of pneumonia or bovine anaplasmosis. Interestingly, there were no recurring cases of pneumonia for animals in the GPB group. Therefore, we believe that future studies should investigate whether the intimate contact with stockpersons promoted by brushing contributes to the earlier detection and treatment of respiratory problems.

With respect to genetic groups, the heifer calves in the present study with a higher proportion of zebu breed had relatively worse temperament, regardless of the treatment applied. To the best of our knowledge, this is the first study to evaluate the temperament of $1 / 2 \mathrm{HG}$ (F1 Holstein $\times$ Gyr) and Girolando (3/4 HG and 5/8 HG) heifer calves; we showed that these groups had lower TD as well as higher CRS, FS, and FD when compared to $7 / 8 \mathrm{HG}$ calves. These differences probably result from the long-term selection of European breeds for low fear of humans, a process that began more recently for most zebu breeds, including Gyr. Therefore, we encourage further research on the temperament of dairy cattle breeds adapted to the tropics, including Girolando and Gyr dairy breeds, which have shown to be viable alternatives for milk production in tropical regions (Berman 2011).

\section{Conclusions}

We conclude that good practices of handling during the preweaning period have long-term beneficial effects, including temperament improvement in weaned heifer calves. However, these practices did not affect overall health or growth. When good practices of handling are combined with brushing, one observes improved human-animal interactions and a reduction in heifers' fear of humans. The lack of differences among treatments during the last assessment suggests that the positive behavioral effects of gentle handling may disappear over time. We therefore recommend close and positive contact with humans for all rearing periods.

\section{Implications}

We suggest that good practices of handling with gentle physical contact be applied from weaning until the precalving period, when heifers are commonly kept in more extensive pasture-based systems. Thus, positive interactions could take place during feeding, including walking softly and talking in a gentle voice. Furthermore, brushing could be done when animals are driven to the corral for routine handlings and at times characterized as sensitive periods, such as when heifers are prepared for their first milking sessions. Future studies should test the hypothesis that the positive effect of brushing on heifers' temperament persists until the onset of their reproductive (first insemination) and productive life (postpartum period and first milking) by reducing their reactivity during artificial insemination procedures and milking.

Acknowledgments This research was funded by Fundação de Amparo à Pesquisa do Estado de São Paulo (Proc FAPESP no. 2011/00813-6). We are grateful to Mauricio Silveira Coelho (owner and manager of Santa Luzia Farm), who made our research possible. This study was part of the lead author's master's thesis in the Graduate Program in Animal Science at the Faculty of Agricultural and Veterinary Sciences, São Paulo State University (UNESP), Jaboticabal, SP, Brazil. 
Compliance with ethical standards This study was approved by the commission for the ethical use of animals of FCAV-UNESP Jaboticabal, protocol number $015 / 14$.

Conflict of interest The authors declare that they have no conflict of interest.

\section{References}

Berman, A., 2011. Invited review: are adaptations present to support dairy cattle productivity in warm climates? Journal of Dairy Science, 94, 2147-2158.

Bertenshaw, C., Rowlinson, P., Edge, H., Douglas, S. and Shiel, R., 2008. The effect of different degrees of 'positive' human-animal interaction during rearing on the welfare and subsequent production of commercial dairy heifers. Applied Animal Behaviour Science, $114,65-75$

Boissy, A.L. and Bouissou, M.F., 1988. Effects of early handling on heifers' subsequent reactivity to humans and to unfamiliar situations. Applied Animal Behaviour Science, 20, 259-273.

Boivin, X., Le Neindre, P., Chupin, J.M., Garel, J.P. and Trillat, G., 1992. Influence of breed and early management on ease of handling and open-field behaviour of cattle. Applied Animal Behaviour Science, 32, 313-323.

Breuer, K., Hemsworth, P.H., Barnett, J.L., Matthews, L.R. and Coleman, G.J., 2000. Behavioural response to humans and the productivity of commercial dairy cows. Applied Animal Behaviour Science, 66, 273-288.

Breuer, K., Hemsworth, P.H. and Coleman, G.J., 2003. The effect of positive or negative handling on the behavioural and physiological responses of nonlactating heifers. Applied Animal Behaviour Science, 84, 3-22.

Burrow, H.M. and Corbet, N.J., 2000. Genetic and environmental factors affecting temperament of zebu and zebu-derived beef cattle grazed at pasture in the tropics. Australian Journal of Agricultural Research, $51,62-155$

Campos, O.F. and Campos, A.T., 2004. Instalações para bezerras de rebanho leiteiro. 80 Circular Técnica- EMBRAPA Gado de Leite. Juiz de Fora, MG.

Charnetski, C.J., Riggers, S., and Brennan, F.X., 2004. Effect of petting a dog on immune system function. Psychological Reports, 95, 10871091.

da Costa, A.N.L., Feitosa, J.V., Montezuma Júnior P.A., de Souza, P.T. and de Araújo, A.A., 2015. Hormonal profiles, physiological parameters, and productive and reproductive performances of Girolando cows in the state of Ceará-Brazil. International Journal of Biometeorology, 59, 231-236.

Field, M.T., 1995. Massage therapy for infants and children. Journal of Developmental \& Behavioral Pediatrics, 16, 105-111.

Fordyce, G., Goddard, M.E., Tyler, R., Williams, G. and Toleman, M.A., 1985. Temperament and bruising of Bos indicus cross cattle. Australian Journal of Experimental Agriculture, 25, 283-288.

Gibbons, J.M., Lawrence, A.B. and Haskell, M.J., 2011. Consistency of flight speed and response to restraint in a crush in dairy cattle. Applied Animal Behaviour Science, 131, 15-20.

Hemsworth, P.H., Coleman, G.J., Barnett, J.L. and Borg, S., 2000. Relationships between human-animal interactions and productivity of commercial dairy cows. Journal of Animal Science, 78, 28212831.
Hultgren, J. and Svensson, C., 2009a. Heifer rearing conditions affect length of productive life in Swedish dairy cows. Preventive Veterinary Medicine, 89, 255-264.

Hultgren, J. and Svensson, C., 2009b. Lifetime risk and cost of clinical mastitis in dairy cows in relation to heifer rearing conditions in southwest Sweden. Journal of Dairy Science, 92, 3274-3280.

Jago, J.G., Krohn, C.C. and Matthews, L.R., 1999. The influence of feeding and handling on the development of the human-animal interactions in young cattle. Applied Animal Behaviour Science, $62,137-151$.

Kerr, S.G.C. and Wood-Gush, D.G.M., 1987. The development of behaviour patterns and temperament in dairy heifers. Behavioural Processes, 15, 1-16.

Krohn, C.C., Jago, J.C. and Boivin, X., 2001. The effects of early handling on the socialisation of young calves to humans. Applied Animal Behaviour Science, 74, 121-133.

Lensink, B.J., Boivin, X., Pradel, P., Le Neindre, P. and Veissier, I., 2000a. Reducing veal calves' reactivity to people by providing additional human contact. Journal of Animal Science, 78, 1213-1218.

Lensink, B.J., Fernandez, X., Boivin, X., Pradel, P., Le Neindre, P. and Veissier, I., 2000b. The impact of gentle contacts on ease of handling, welfare, and growth of calves and on quality of veal meat. Journal of Animal Science, 78, 1219-1226.

MacKay, J.R.D., Turner, S.P., Hyslop, J., Deag, J.M. and Haskell, M.J., 2013. Short-term temperament tests in beef cattle relate to long-term measures of behaviour recorded in the home pen. Journal of Animal Science, 91, 4917-4924.

Miranda, J.E.C., Ribeiro, A.C.C.L., Campos, O.F. and Novaes, L.P., 2003. Cria e Recria de fêmeas leiteiras: passo a passo. Comunicado Técnico- EMBRAPA Gado de Leite, Juiz de Fora, MG.

Pajor, E.A., Rushen, J. and de Passillé, A.M.B., 2000. Aversion learning techniques to evaluate dairy cattle handling practices. Applied Animal Behaviour Science, 69, 89-102.

Petherick, J.C., Doogan, V.J., Venus, B.K., Holroyd, R.G. and Olsson, P., 2009. Quality of handling and holding yard environment, and beef cattle temperament: 2 . Consequences for stress and productivity. Applied Animal Behaviour Science, 120, 28-38.

Rushen, J., Munksgaard, L., de Passillé, A.M.B., Jensen, M.B. and Thodberg, K., 1998. Location of handling and dairy cows' responses to people. Applied Animal Behaviour Science, 55, 259267.

Rushen, J., Munksgaard, L., Marnet, P.G. and de Passillé, A.M.B., 2001. Human contact and the effects of acute stresse on cows at milking. Applied Animal Behaviour Science, 73, 1-14.

Sant'Anna, A.C., Paranhos da Costa, M.J.R., Baldi, F. and Albuquerque, L.G., 2013. Genetic variability for temperament indicators of Nellore cattle. Journal of Animal Science, 91, 3532-3537.

SAS (SAS Institute Inc.), 2011. SAS® 9.3 System Options: Reference, Second Edition. Cary, NC: SAS Institute Inc.

Schmied, C., Boivin, X. and Waiblinger, S., 2008a. Stroking different body regions of dairy cows: Effects on avoidance and approach behavior toward humans. Journal of Dairy Science, 91, 596-605.

Schmied, C., Waiblinger, S., Scharl, T., Leisch, F. and Boivin, X., 2008b. Stroking of different body regions by a human: Effects on behaviour and heart rate of dairy cows. Applied Animal Behaviour Science, $109,25-38$.

Schuelze-Westerath, H., Gygax, L. and Hilmann, E., 2014. Are special feed and being brushed judged as positive by calves? Applied Animal Behaviour Science, 156, 12-21.

Solomon, G.F., Levine, S. and Kraft, J.K., 1968. Early experience and immunity. Nature, 220, 821-822.

Suomi, S.J., 1995. Touch and immune system in rhesus monkeys. In: Pages $89-104$ in Touch in Early Development. T. M. Field, ed. Psychology Press, New York, NY. 
Svensson, C. and Hultgren, J., 2008. Associations between housing, management, and morbidity during rearing and subsequent first-lactation milk production of dairy cows in southwest Sweden. Journal of Dairy Science, 91, 1510-1518.

Vasseur, E., Rushen, J., de Passillé, A.M.B., Lefebvre, D. and Pellerin, D., 2010. An advisory tool to improve management practices affecting calf and heifer welfare on dairy farms. Journal of Dairy Science, 93, 4414-4426.

Waiblinger, S., Menke, C., Korff, J. and Bucher, A., 2004. Previous handling and gentle interactions affect behaviour and heart rate of dairy cows during a veterinary procedure. Applied Animal Behaviour Science, 85, 31-42.

Waiblinger, S., Boivin, X., Pedersen, V., Tosi, M.V., Janczak, A.M., Visser, E.K. and Jones, R.B., 2006. Assessing the human-animal relationship in farmed species: a critical review. Applied Animal Behaviour Science, 101, 185-242.

Waltner-Toews, D., Martin, S.W. and Meek, A.H., 1986. The effect of early calf hood health status on survivorship and age at first calving. Canadian Journal of Veterinary Research, 50, 314-317. 